\title{
花崗岩の変形と破壊について
}

\author{
京都大学防災研究所 松島 昭 吾 \\ (啫和 31 年: 2 月 20 日受理)
}

\section{On the Deformation and Fracture of Granites}

\author{
Shōgo Matsushima \\ Disaster Prevention Research Institute Kyoto University
}

(Received Feb. 20, 1956)

To consider the occurrene of earthquake, it is neccesary to know the mechanism of deformation and fracture of silicate rocks. Uuder the experiments of the short-time simple compression test, granites have the property represented by the Maxwell-Kelvin complex. Retardation time of the Kelvin body is about 7-9 seconds, independent of stress and rock classification. Fluidity of the maxwell body increases rapidly near the rupture, and the elastic after effect is increasing with stress multification.

The strain ratio of longitudinal to lateral direction is largely above the value of 0.5 for granites near the rupture, that is, there is volume expantion in this region. However, this effect does not arise instantaneously with loading, but depends on the plastic flow after stress added; and the longer the duration, the larger becomes the volume inflation. We suppose, it is because of cavity augmentation inner the specimen on the occasion of fracture.

\section{§1.は し がき}

岩石の弾性の問題については, 今世紀のはじめ頃から非常に数多くの実験的研究がなされて 来た。最初に取扱われた問題は, 地震波の伝播の媒体となる岩石の弾性率についてであつた。

長岡・日下部・Zisman1) らによつて, Young 率・剛性率・Poisson 比が測定された。最近で は超音波を用いる打法がさかんに行われている。㕛体積弾性率については, 主として地球内部 構造論の要求から, Adams・Birch ${ }^{2)}$ につて, 高静水圧装置を用いて精しく測られた.

しかし地質学的に見れば，地殼は完全弾性体には程遠いものであつて，永い年月の間にはか なり大きな永久変形をすることが，地款の櫭曲などによつて観察される．又いろいろな方法で 測定した弾性率の值の喰違いを説明するためには，岩石はとうてい完全弾性体と考光るわけに はいかない，高圧実験法の発達にともなつて，Adams・Griggs ${ }^{3)}$ らによつてなされた，高圧 下での大理石や石灰岩などの変形は，このことを一そう明らかに物語つている．Griggs ${ }^{4)}$ は常 温常圧の下でも炭素質岩石がかなりクリープをすることを示した。

所で, 地震学の立場から地震の発生の問題を考学てみよう。地震の原因を何等かの理由で地 殼を構成している岩石が破壞するためであると考觉ると，変形に引続いて岩石の破壞の問題を 
取上げてみる必要がある.地震の発生する所は少くとも花崗岩や玄武岩などの硅素質岩石から 成立つている層及びょり深い所であると思われるから, 破壊の問題においては特に硅素質岩石 についての実験が重要であろう.

Robertson ${ }^{5)}$ は最近の論文で破壊の機構に対して効果を及淁す因子として，応力条件・温度 ・組成・時間・物理的性質などいくつかの項目をあげている。同じ論文で彼は, 炭素質岩石と 硅素質岩石の破壊強度に対する応力条件の効果について述べている. Griggs ${ }^{6)}$ は応力条件及 び時間の効果を大理石と石灰岩について測定した。温度の効果についても最近幾多の実験が報 告されている.

しかしながら，依然として岩石の破壊の機構は極めて複雑であり，それに効果を及ぼすいく つかの因子を地震の発生と関連させることは容易ではない.いろいろな方から一歩一歩成果 を積み重ねて行かねばならないだろう。

ここに報告する実験は, 常温常圧の下に沶いて，(1) 岩石の粘弾性性質と応力によるそれら の性質の変化 (2) 破壞点附近での変形状態の特異性を, 調べるために行つたものである.

\section{§. 試料}

実験には上に述べた理由によつて花崗岩系統の岩石のみを用いた。勿論地表で得られた花崗 岩は地殼内部のそれとは物理的化学的性質共にかなり垔違があるだろうが，これらを用いた実 験結果は地殼深部の状態を知るのにかなり役立つに相違ない.

試料の大いさは実験の便宜上, 長さ $6 \mathrm{~cm}$ 直径 $3 \mathrm{~cm}$ 及び長さ $4 \mathrm{~cm}$ 直径 $2 \mathrm{~cm}$ の円柱形 のものとした。また両底面は殆んど平行に且つ光学的平坦に近いまで研磨した．それで外的な 原因による応力の不均衡は殆んど除くことが出来た。

試料についての詳しいデータは第 1 表に示す.

Table 1.

\begin{tabular}{|l|l|c|c|c|}
\hline \multicolumn{1}{|c|}{ Name No. } & Locality & Density & $\begin{array}{c}\text { Strength } \\
\mathrm{kg} / \mathrm{cm}^{2}\end{array}$ & \multicolumn{1}{|c|}{ Note } \\
\hline Biotite granite 5-4 & Ajimura Kagawa-ken & 2.67 & 2700 & Fine grain \\
\hline Biotite granite 24-1 & Kitashirakawa Kyoto-fu & 2.63 & 1580 & Rough grain \\
\hline Quartz monzonite 18-1 & Awokiko Nagano-ken & 2.63 & 2000 & \\
\hline Gneissose granite 21-1 & Shichikucho Hyogo-ken & 2.67 & 1770 & Parallel to schistosity \\
\hline Two mica granite 20-3 & Kitakanaki Kyoto-fu & 2.62 & 2130 & Rather fine \\
\hline Pegmatite 25-1 & Nahegicho Gifu-ken & 2.56 & 1420 & \\
\hline Biotite granite 2-4 & Okazakishi Aichi-ken & - & 1550 & Rather rough \\
\hline
\end{tabular}




\section{§3. 装置及び測定器}

材料の機械的性質の試験方法はいろいろ行われている。すなわち圧縮・引張・挸み・㨭り・ 静水圧縮等である. 試験の方法によつてその強度や变形の様子などはひどく異る場合が多い。 例光ば岩石では, 引張り試験の場合には引張り強度が極めて低いために破壊は全く引裂き破壊 であつて，亖りがないために非常に brittle な性質を示す．Griggs ${ }^{7)}$ は引張り強度の低い原因 を試験方法による応力の不均衡に依るといつているが，それよりるやはり張力に対する抵抗力 の低さに原因があるように思われる。暁み試験などでも同様なことがいわれるだろう。

他方圧縮試験では, 弾性論的には張力成分が作用しないため破壊強度はずつと增大し, 破壞 の前にはかなり塑性的な性質を示して来る。したがつて材料の機械的性質を詳しく知るために は，いろいろな応力条件の下での試験を行わねばならない。

しかしながら㞸石は一般に brittle な性質が強いために, 引張り試験や㨝り試験は極めて困 難である。これは試料を保持する方法がむつかしく応力集中が起るためである．高圧下での引 張り試験ではこの難点は除かれる.

以上のよ5な理由からこの実験では压縮試験のう法を用いた：第 1 図にこの実験に用いた試 験機の概略を図示する。この試験機では最大 $20,000 \mathrm{~kg} / \mathrm{cm}^{2}$ までの応力を与えることが出来る。

試料 $\mathrm{S}$ は上端では force-equalizer F を挾えでピ ストン $\mathrm{P}_{1}$ とまた下端では直接ピストン $\mathrm{P}_{2}$ と接 している.それで試料の両端と $\mathrm{P}_{2}$ 及び $\mathrm{F}$ との 間の摩擦が变形に対して影響を与えることが予期 される。そのために試料は澊形に膨れ出すである う。しかしながら後で述べるように弾性限界内で はこの現象はそれほど顕著ではなく，破壊点附近 で試料がかなり flow しはじめてからこの効果が

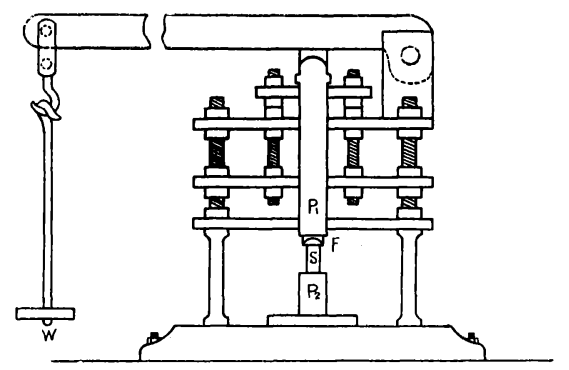

Fig. 1. Schematic diagram of compression apparatus used for this experiments. はつきりあらわれて来た。

また前述の摩擦を緩和させるために錫䇴を間に挾んだ. Bridgman ${ }^{8)}$ は鉛箔を用いるのがよ いと述べている・いずれにしても剪断抵抗の低い金属箔を使壳ば摩擦はかなり減少させること が出来るようである。

卒の測定には，可変抵抗型丕計を用いた。この歪計は試料に細い金属抵抗線を貼付し，丕に 応じて金属線が伸縮して抵抗值を変化するのを利用したものであつて，この変化を増门拡大し て記録し，或は読取るようになつている.

この丕計の利点は感度がよいこと，取扱いが簡単であること小さな試料に対しても使用出来 
ることである。しかし精度はあまりよくなくて最大 $5 \%$ 位までの誤差がある。しかし偏倚の 方向は常に一定でまた誤差の割合もほぼ一定であるから，相対的な変化を知るには大変便利で ある．絶対值を知るには他の機械的な方法によつて補正を充分行つて持けばよい，も一つの短 所は大きな丕に対しては直線性が悪くなることである。しかしこの実験では岩石があまり大き

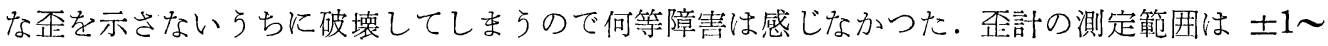
$30,000 \times 10^{-6}$ また测定誤差は $\pm 0.5 \sim 3 \times 10^{-6}$ で $150 \mathrm{c} / \mathrm{s}$ の振動歪まで測定可能である。但し 併用した電流計の固有週期は $15 \mathrm{c} / \mathrm{s}$ である.

\section{§4. 花崗岩の粘弾性性質}

岩石に一定の時間を括いてだんだんと応力を加えてゆくと試料は応力の加えられた方向に変 形していつて遂に破壊する。しかしそれは応力が加えられたとき瞬間的にすつかり変形してし まわないで，粘性のためにその後も次第に変形が進行してゆく．これは一般にクリープと呼ば れているものである。クリープには荷重後比較的短い時間で減衰する遷移クリープと，ほぼ一 定の割合で变化が続いてゆく定常クリープ2の種類がある。しかしながら戦密にしらべて見る そその機構はもつと複雑であると思われる。また物質によつても相違があるだろう。

ある物質の機械的な性質を詳しく知るためには，このようなクリープの行動をつまびらかに 調ベることが必要である。

岩石のクリープについては Griggs9) が大理石や石灰岩等について研究しているが，この実 験では花崗岩の試料に圧縮応力を加光て後約 100 秒前後の間に示される flow の状態を測定 して, 近似的に粘弾性構造を求め, それが破壊するときどのように変化するかをしらべた。こ の実験では 1 秒以内での変化は求めることが出来なかつたが，これは波の伝播に大きな影響 をもつものと思われるので時間的にもつと精密な測定が望まれる.

第 2 図は約 100 秒余りの間を特いて約 50 〜 $100 \mathrm{~kg} / \mathrm{cm}^{2}$ の応力を加えて行つたとき，歪が 時間と共に増して行くことを示したものである. 今このようにして得た昰と時間との関係から 実験式を導くために，片対数グラフに時間軸に対数をとつて書きうつして見る。第 3 図はその 一例である。このような図が 1 つの試料について，いろいろな応力に対応していくつか得ら れる。

これらの眓から実験式としては

$$
S=A+B e^{-a t}+C t
$$

を用いるのがもつとも都合よいと考光られる. 第 3 図に plot したデータから常数 $A \cdot B \cdot C$. $\alpha$ を求め, これを(1) 式に代入して得た曲線を同じく第 3 図に描いた。曲線と実測值はかな りよく一致している。但し（1）式に和いて，s は歪 $t$ は時間（秒）である. 


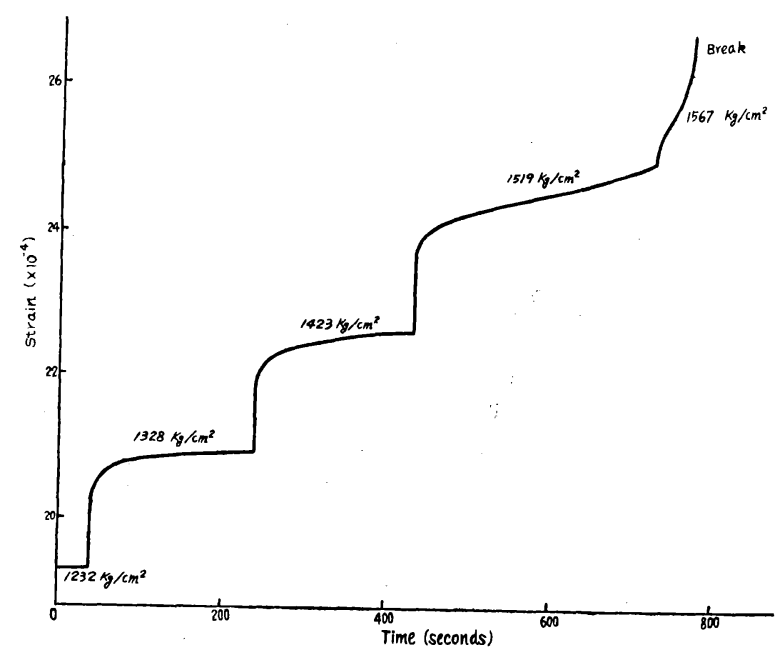

Fig. 2. Strain-time curve under successive loading for granite. Kitashirakawa granite 24-1

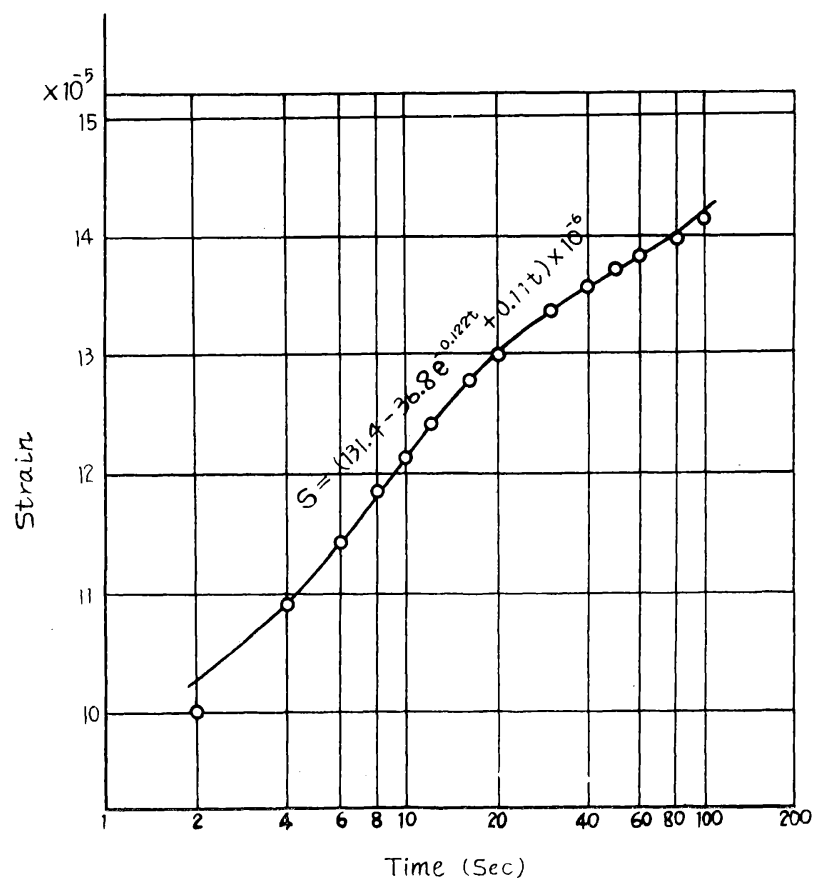

Fig. 3. Strain-time relation under constant stress (in this case $946 \mathrm{~kg} / \mathrm{cm}^{2}$ ) plotted on semi-logarithmic paper. Kitashirakawa granite 24-1 


$$
\left.\begin{array}{l}
A=\Delta p / \varepsilon_{H}+\Delta p / \varepsilon_{K} \\
B=-\Delta p / \varepsilon_{K} \\
C=p / \lambda_{N} \\
\alpha=\varepsilon_{K} / \lambda_{K}
\end{array}\right\}
$$

と㧊くと(1) 式は

$$
S=\frac{\Delta p}{\varepsilon_{H}}+\frac{\Delta p}{\varepsilon_{K}}\left(1-\epsilon^{-} \varepsilon_{K} / \lambda_{K} t\right)+\frac{p}{\lambda_{N}} t
$$

となる。この式は $p_{0}$ なる応力下にめつた物質が更に $\Delta p$ なる応力を受けたとき生ずる歪の㬨 間的変化を示するのであつて（但し $\left.p=p_{0}+\Delta p\right)$, この物質の構造式が $\boldsymbol{H}-\boldsymbol{N}-\boldsymbol{K}=\boldsymbol{M}-\boldsymbol{K}$ で あることを意味する。

したがつて花崗岩は 100 秒前後の短時間試験に対しては Maxwell-Kelvin 体の構造をるつ ことが結論される。

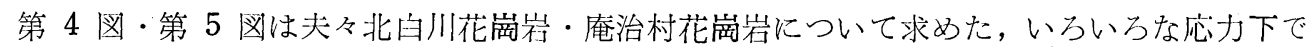
の $\varepsilon_{K} \cdot \lambda_{N} \cdot \alpha$ の值である. 但し図に执いて $\phi_{N}=1 / 3 \cdot 1 / \lambda_{N}$ であつて，これは Maxwell 体の流 動度を表わすものである。また $1 / \alpha=\varepsilon_{K} / \lambda_{K}=\tau_{K}{ }^{\prime}$ と紋くと，これは Kelvin 体の遅延時間に 相当するものといえよう。

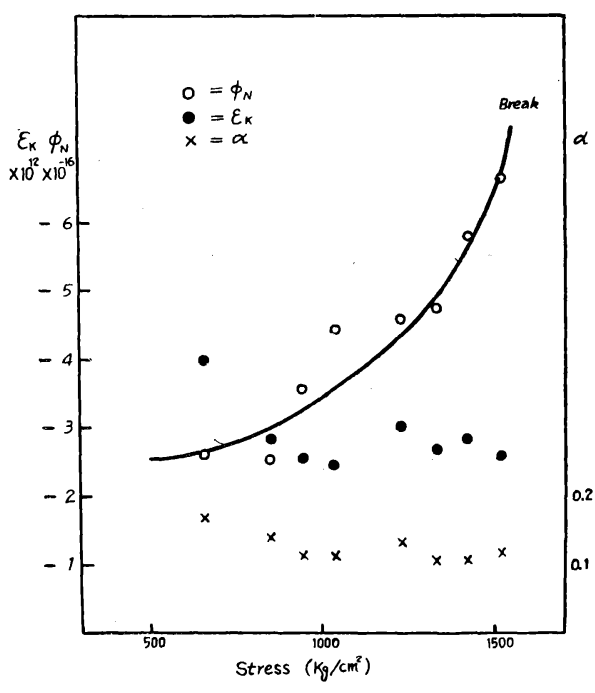

Fig. 4. The values of $\phi_{N}, \varepsilon_{K}, \alpha$ for various stresses. Kitashirakawa granite 24-1

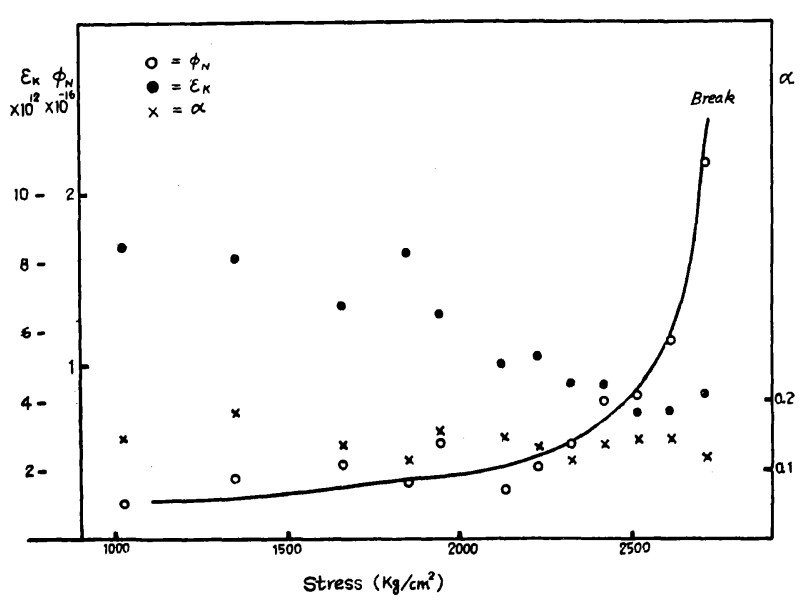

Fig. 5. The values of $\phi_{N}, \varepsilon_{K}, \alpha$ for various stresses. Ajimura granite 5-4

\section{§5. 破壞点附近での特異な变形状態}

円柱形の試料に軸方向に圧縮応力を加光て行くと，試料は縦方向に縮むと同時に横方向（半 径方向）に膨れてくる．完全弾性体であれば縱へ縮も割合と横へ膨れる割合との比（すなわち 
Poisson 比）は大体一定であつて, 通常その值は 0.25 位である.そして塑性領域に入るとそ こでは通常体積変化はないとみなされるから，その值はほぼ 0.5 位となるだろう，岩石に関 しては静的な測定によると縦と横との歪の比は一定値ではなくて，最初 $0.1 〜 0.2$ 位から応力 の增加にともなつて次第に增し，やがて $0.25 \sim 0.3$ 位の值に到達することが報告されてい る ${ }^{10)}$. 所で岩石が塑性領域をるつているとすると，そこでは上記の比がどのように変化するか を知ることは，破壊機構をしらべる上に必要なことがらであろう．

Bridgman ${ }^{11)}$ は体積膨張計を用いて, Soapstone ·大理石・輝緑岩乞の他の試料について単 純圧縮による体積変化を測定した，その結果 Soapstone・大理石は破壊点附近で急激に体積が 増加することを示した。このことはその領域で縦と横の歪の比が 0.5 を越えることを示すも のである.

この実験は破壊点附近で縦及び横の歪がぞのように变るか，またその㭙間的変化がぞうなる かを測る目的で行つたものである.第 6 図に示すよ5に試料に縦方向・横方向中央・横方向上 端に抵抗線グージを貼りつけて歪の変化を直接測定した。 横方向の中央と上端にグージを貼付したのは，ピストンとの 摩擦によつて試料が樽形に膨れるためである.

今試料が完全な円柱形で且つすべての方问に一様に変形 するものとする．変形前の半径を $r$, ゲージの長さを $l$, ゲ 一ジの両端の間の円周角を $\theta$ とし, 变形後半径が $r+\Delta r, ケ ゙$ 一ジの長さが $l+\Delta l$ になたとする。一様変形であるから $\theta$ は不変である。したがつて

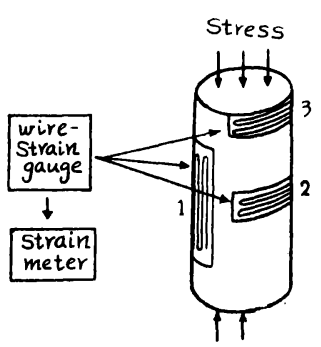

Fig. 6. Schematic diagram of strain measurements. (1) longitudinal (2) lateral (middle) (3) lateral (upper)

$$
\begin{gathered}
l=r \theta \\
l+\Delta l=(r+\Delta r) \theta \\
\therefore \quad \frac{\Delta l}{l}=\frac{\Delta r \theta}{r \theta}=\frac{\Delta r}{r}
\end{gathered}
$$

それ故佃周方向に貼つたゲージは，その点での半径方向への歪を指示するものと考えてよいで あるち。

実験力法は前節の実験と同じように約 100 秒余りの間を虬いて一定の忍力をだんだん加え ていつた．歪計の読取りは加重後 100 秒たつてから行つた．上記の方法て測定した結果を第 7 図〜第 9 図に示す.使用した岩石は片麻状花崗岩 (兵庫県志筑) 石英モンゾン岩（長野県青 木湖）同雲母花崗岩（京都府北金岐）である. 但し両雲母花崗岩では横方向上端の測定は行わ なかつた。 
石英モンゾン岩. 第 7 図に扔いて見られるように横方向では歪の小さいらちは, 上端も中 央と殆んど同じように膨れている．丕が大きくなり且つとの增加のしかたが大きくなつてくる と，当初予期されたようにピストンとの摩擦の効果が表われて来て，中央部の膨れが䦌端部の それをはるかに凌駕して澊形に変帅してくる，そして縦と横との歪の比は破壊に近づくにつれ て中央両端共に 0.5 を越えてしまうが，中央部ではそれが特に著しい。このことから試料は破 壞点附近で急激な体積膨張をしていることが推察される。

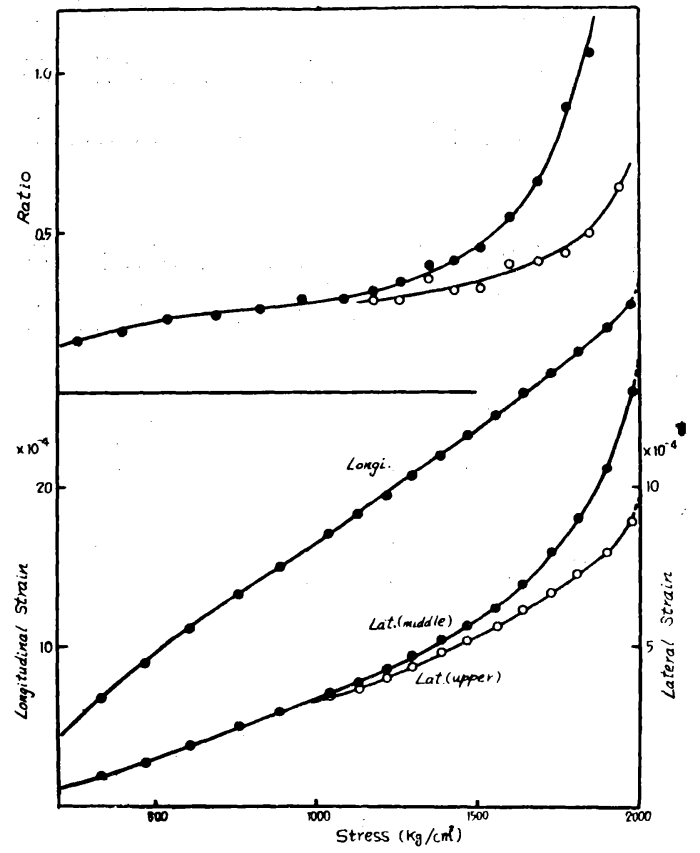

Fig. 7. Stress-strain curve of longitudinal and lateral, and its ratio. quartz monzonite 18-1

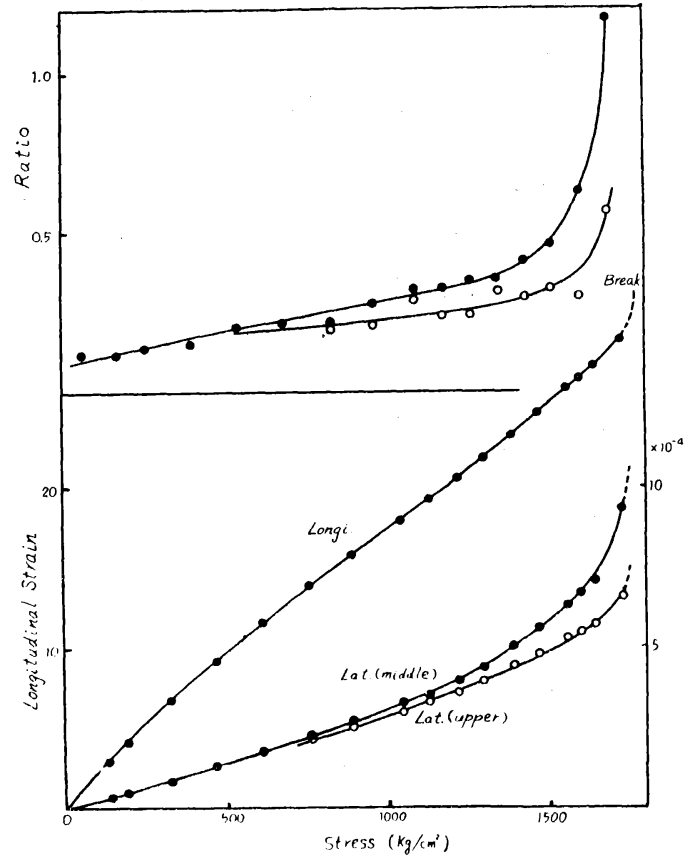

Fig. 8. Similar to Fig. 7. gneissose granite $21-1$

片麻状花崗岩．石英モンゾン岩と同じょうに樽形の変形と体積膨張が観察されるが，ままり 顕著ではなくて破壞点のごく近傍でその効果があらわれて来る。すなわち塑性領域が比較的少 ないと見てよいだろう。このことは動力变成作用の結果加工硬化を受けたためと思われる。

両雲目花崗岩。この試料では横方间上端の歪は測定しなかつたけれども，恐らく前述の岩石 と同様に破壤点附近でかなりの体積膨張があると結論してよい。

偖て，第 4 節の実験に抢いて，岩石が破壊点附近で塑性的性質を增すために忍力を一定に保 つて特いても縦方向の歪が時間と共に増してゆくことを観察した。同様にして横方向の歪もま た時間と共に增してゆくことが考㝋られるし，したがつて体積变化の状態も時間との関係に拉 いて求められるだろう。 
そのような現象をしらベるためにペグマタイト(岐阜県苗木)の陚料を使つて定応力下で 3 のつの歪の成分の時間变化を連続的に記録した。第 10 眼に示ず写真はその記録の一部であ る.この眼で判るように破壞点附近では横方向（上端・中央其）の flow の量は縦方向のそれ

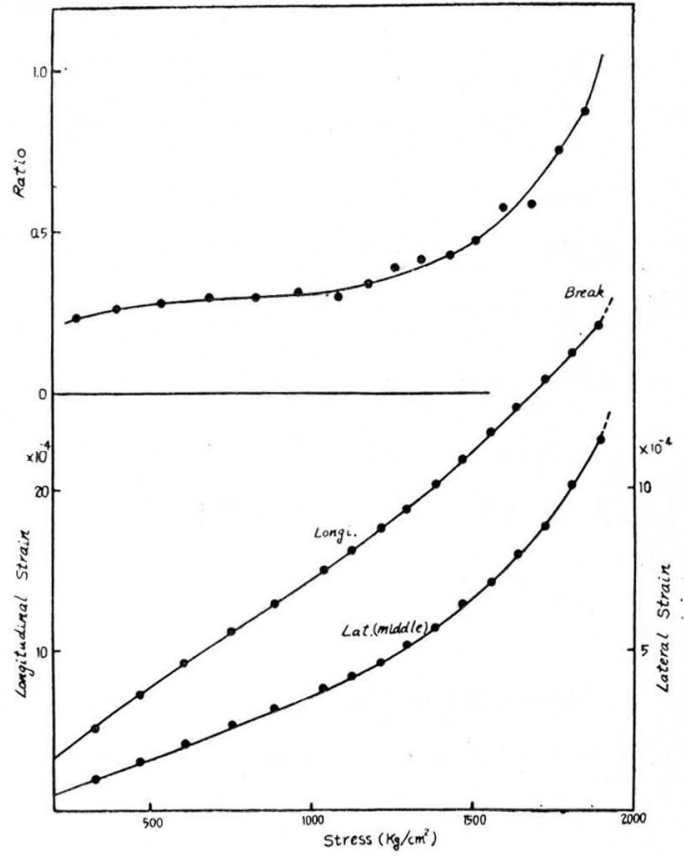

Fig. 9. Similar to Fig. 7.t wo mica granite 20-3

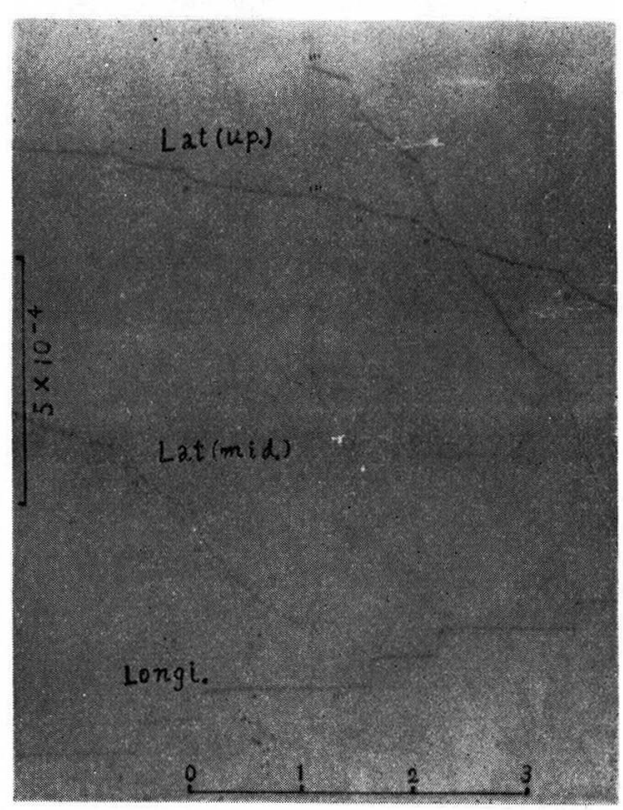

Fig. 10. Photographic record of longitudinal and lateral strain varying with time.

に比べてはるかに大きく, 数倍以上にも達している. 他方, 加重直後の変形 (弾性的な変形) の比は 0.5 以下である.従つて第 7 汹〜第 9 汹に示した縦と横の歪の比に関する曲線が破 壞点附近で 0.5 以上に達しているのは, 全く flow の影響によるものであると結論される.

また体積の膨張量は応力が与えられている畤間に密接な関係があつて，その㭙間が永いほど 膨張の量も大きい，京様に応力が大きいほど体稓增加の時間的割合も大きいことがわかる.

体積增加の実際的な数值に関しては, 試料が椎形に变形するために詳しく知ることが出来な からた。これは体積膨張㖕を朋いるか，或は㭬力向に多数のゲージを貼付することによつて測 定出来るだろう。

\section{§6. 岩石の破壞の機構について}

Griggs ${ }^{12)}$ は破壞の機構として引裂破壞と之り破壞の 2 種をあげている.また通常の破壊では この 2 種が混つて起り, 岩石の圧縮破壊の場合にも張力破壊の成分があることを報告している。 前節の実験の結果, 横方向への flow が破壊点附近で著しく大きくなつていることがわかつ 
たが，この現象は引裂破壞の効果が極めて大きなるのであることを示していると思われる。宕 石は一般に剪断応力に対するよりも張力に対する抵抗力がずつと低く，且つ沢山の小さな pore や crack を内蔵している。したがつて圧縮応力が加えられてもとれと直角な方向に張力成分

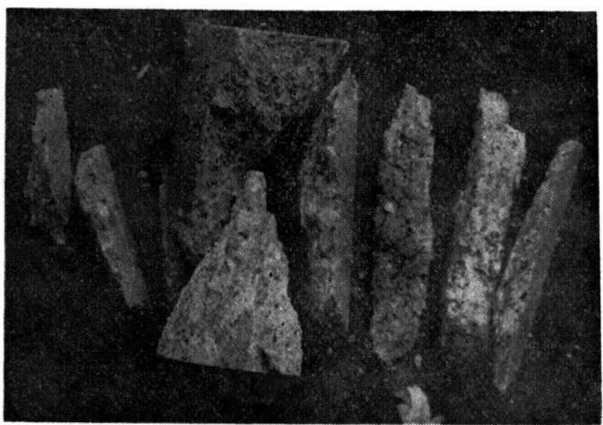

Fig. 11. Ruptured specimen of Okazaki granite $2-4$ が生じ，それに対する抵抗が低いために crack は次第に增大して内部に沢山の空隙が生ずる. このため破壊に近づくにつれて体積がむしろ膨 張する現象があらわれるのであろう。この効果 は剪断応力と相俟つて破壊を促進する。円柱試 料を用いた場合之り角は大体 $30^{\circ}$ 位であり，ま たその側面には縦方向に大きな亀裂が認められ る。これは円周方向に張力が働いたことを示す ものであろう、第 11 図に破壊した試料の写真 を示す。

\section{$\S 7$. 結}

論

1. 岩石は 100 秒前後の短時間試験に和いては Maxwell-Kelvin 体で近似することが出来 る。しかしもつと短い時間及びもつと長期に亘つての観測によつて更によい近似に書きかえら れるべきだろう。

2. Maxwell 体の流動度 $\phi_{N}$ は長期のクリープ試験から得られるものよりるずつと大きな 值を得た。これは恐らく緩和時間のずつと大きい Kelvin-type flow の極く初期を観測したた めであろう。

3. 強度の低い北白川花崗岩は強度の大きな庵治村花崗岩よりずつと大きな $\phi_{N}$ の値を示し ている。このことは一般的にいえるだうう。

4. $\phi_{N}$ の値は応力が増すに従つて幾分か增加の傾问を示し, 破壞点附近てこの傾向は顕著 である。このことは破壞点附近で僅かながら塑性領域をもつものとみなしてよいことを意味す るだうう・

5. $\alpha$ すなわち $\tau_{K}^{\prime}$ は灾力に対して無関係にほぼ一定値を保つ。 その值は大体 7 9 秒で める。また試料の種類にも依らないらしく思われる。

6. $\varepsilon_{K}$ は応力の增加によつて次第に小さくなつてゆく傾向を示ず.すなわち弾性余効の効 果が次第に大きくなつてゆくことを示す。

7. 花崗岩類は破壊点附近で緃と横の丕の比が 0.5 以上に達する.このことはその領域で体 積膨脹があることを意味する。 
8. 体積膨脹の量は強度の大きいち密な岩石或は変成を受けた岩石ほど少ないようである。

9. しかし体積の増加は, 荷重した瞬間における弾性的な変形によつては生じないで, その 後続いて起る flow によるものである。したがつて応力を一定に保つて特いても，㬨間の経過 につれて体積の膨脹量が增して来る。

10. 体積增加の時間的な剨合は応力が大きい程大であり，破壞点の極く近くでは縱横の䅉の 比は数倍以上に達する.

\section{§8. あと がき}

終りにあたつて，いろいらと御親切に指導を給わつた佐々教授に深く感謝すると共に垁験に 協力して頂いた北村俊吉氏・森本喜一郎氏・長谷川雅一君の諸氏に厚く御礼を申します。

\section{文献}

1) H. Nagaoka, Publ's E. I. C. No. 4 (1900) p. 47.

S. Kusakabe, J. Coll. Sci. Tokyo, 20, Art X (1904-5).

W. A. Zisman, Proc. Nat. Acad. Sci., 19 (1933) p. 653.

2) L. H. Adams and E. D. Williamson, J. Frank. Inst., 195 (1923) p. 475.

L. H. Adams and R. E. Gibson, J. Wash. Acad. Sci., 21 (1931) p. 381.

A. F. Birch and R. R. Law, Bull. Geol. Soc. Amer., 46 (1936) p. 1219.

3) F. D. Adams and J. T. Nicholson, Phil. Trans. Roy. Soc. London, Ser. A, 195 (1901) p. 363 .

D. Griggs, J. Geol. 44 (1936) p. 541.

4) D. Griggs, J. Geol. 47 (1939) p. 225.

5) E. C. Robertson, Bull. Geol. Soc. Amer. 66 (1955) p. 1275.

6) loc. cit.

7) A. F. Birch, D. Griggs and others, "Handbook of Physical Constants" (1924).

8) P. W. Bridgman, "Large Plastic Flow and Fructure" New York (1952).

9) loc. cit.

10) loc. cit.

11) P. W. Bridgman, J. App. Phys. 20 (1949) p. 1241.

12) loc. cit. 